\title{
Identification and Pathogenicity of Pythium on Soybean in North Dakota
}

\author{
Kimberly K. Zitnick-Anderson and Berlin D. Nelson Jr., Department of Plant Pathology, North Dakota State University, Fargo 58108
}

\begin{abstract}
Zitnick-Anderson, K. K., and Nelson, B. D., Jr. 2015. Identification and pathogenicity of Pythium on soybean in North Dakota. Plant Dis. 99:31-38.

The oomycete Pythium comprises one of the most important groups of seedling pathogens affecting soybean. There has been limited research on Pythium spp. pathogenic on soybean in the northern Great Plains. The objectives of this research were to isolate and identify Pythium spp. infecting soybean in North Dakota and to test their pathogenicity. Identification of Pythium spp. was achieved using molecular techniques and morphological features. A total of 26 known Pythium spp. and three unknown species were recovered from soybean seedling roots collected from 125 fields between 2011 and 2012. In 2011, the three most abundant species isolated were P. ultimum, Pythium sp. (unknown; GenBank HQ643777.1), and P. heterothallicum, representing 21,16 , and $12 \%$ of 2,675 isolates, respectively. More species and

isolates were obtained in 2011, a wet and cool year, compared with 2012, which was dry and warm. The majority of Pythium spp. caused pre-emergence damping-off on soybean with less than $50 \%$ emergence in a 2-week test using infested soil at $23^{\circ} \mathrm{C}$. In contrast, in the presence of $P$. orthogonon, $P$. nunn, or $P$. rostratifingens there was approximately $80 \%$ or greater emergence and most plants survived for several weeks, although lesions were observed on roots. Mortierella spp., a zygomycete, was commonly isolated along with Pythium spp. in 2012, but not in 2011. This is the first report of $P$. kashmirense, $P$. minus, $P$. periilum, $P$. rostratifingens, $P$. terrestris, $P$. viniferum, and $P$. violae as pathogens of soybean seedlings. In addition, this is the first report of $P$. kashmirense, $P$. viniferum, and P. terrestris in the United States.
\end{abstract}

Pythium, a genus within the oomycetes, comprises one of the most important groups of seedling pathogens affecting soybean (Glycine $\max$ (L.) Merr.), causing both pre- and post-emergence damping-off. Oomycetes are fungal-like, but are in the chromalveolate superkingdom (5). Numerous Pythium spp. are known to be pathogenic on soybean $(7,17,24)$. Multiple Pythium spp. have been isolated from a single plant, suggesting a Pythium spp. complex (34) is involved in some diseases. A Pythium spp. complex on a single plant creates difficulty in assessing which Pythium sp. is the primary pathogen. Proper identification of the species causing infection and disease is important for developing effective management strategies. Pythium spp. can react differently to different fungicides (7); therefore, one cannot assume that all Pythium spp. can be managed with the same fungicide active ingredient. Infection by Pythium spp. typically results in pre- and post-emergence damping-off that affects soybean seeds, seedlings, and to a lesser extent, adult plants (14). Symptoms may also include disintegration of the seed and discoloration of the hypocotyl and roots (14).

The United States is a major soybean producer with 30.8 million ha in 2012 and 1.8 million ha located in North Dakota (http:// www.nass.usda.gov/Statistics_by_State/North_Dakota/). Dampingoff can be devastating, especially during wet years, and is of economic importance in the soybean industry. It is important to determine the role Pythium spp. play in damping-off and seedling disease of soybean.

There has been limited research on Pythium spp. present in soybean in the northern Great Plains, and no in-depth investigations on Pythium spp. conducted in North Dakota $(10,17,24,30)$. It is currently not known which species are soybean pathogens in North Dakota or how important they are in disease development. The objectives of this research were to identify the Pythium spp. present in North Dakota on soybeans and determine if they were path-

Corresponding author: B. D. Nelson Jr., E-mail: berlin.nelson@ndsu.edu

* The $\boldsymbol{e}$-Xtra logo stands for "electronic extra" and indicates that one supplementary figure and two supplementary tables are available online.

Accepted for publication 7 July 2014.

http://dx.doi.org/10.1094/PDIS-02-14-0161-RE

(C) 2015 The American Phytopathological Society ogenic on soybean. The results of the research can be used to develop management programs for Pythium diseases of soybean. A preliminary report of this research was published (36).

\section{Materials and Methods}

Collection of plants. In June of 2011 and 2012, soybean seedlings were collected from 87 and 38 soybean fields, respectively, in 20 counties in the eastern half of North Dakota, the primary soybean production area of the state (Supplementary figure). Fields sampled in 2012 were different from those sampled in 2011. Counties selected for sampling represented the area of largest soybean production in the state and had been in soybean production for approximately 20 years or longer. Soybean fields were chosen at approximately 6 to $8 \mathrm{~km}$ intervals between fields. Ten entire seedlings including roots were arbitrarily collected at the first trifoliate leaf stage from each field with approximately $2.5 \mathrm{~m}$ between plants. Plants were sampled regardless of showing symptoms of disease. GPS coordinates were recorded for each field (Supplementary table A). Seedlings were transported to the laboratory in coolers and were gently rinsed with lukewarm tap water to remove soil particles and lightly patted dry with paper towels. Seedlings were processed immediately or stored at $4^{\circ} \mathrm{C}$ and processed within $24 \mathrm{~h}$ of collection.

Isolation and identification of isolates. Nine (2-cm-long) cuttings were made arbitrarily from the roots of each plant and each cutting was separately placed onto selective medium PARP+B (primaricin, sodium ampillicin, rifampicin, pentachloronitrobenzene, and benomyl) water agar (WA) (16) using the under the block technique (31). Pythium spp. can be present on seedlings regardless of the presence of disease symptoms, therefore justifying the arbitrary root cuttings from every plant collected. Root samples were incubated at $23 \pm 2{ }^{\circ} \mathrm{C}$ in an incubator for $72 \mathrm{~h}$ then examined at $10 \times$ to $20 \times$ magnification using a $\mathrm{BX} 43$ clinical microscope (Olympus, Center Valley, PA) under phase one lighting for presence of Pythium-like growth. Defining characteristics, such as coenocytic hyaline hyphae with flowing protoplasm, were used as criteria to select cultures for transfer. Subcultures were taken from the tips of hyphae that fit this criterion, and plated onto another selective medium, $\mathrm{P}_{10} \mathrm{VP}$ V8 agar, containing pentachloronitrobenzene, primaricin, and vancomycin (33). Subcultures were grown for 3 days and then transferred to potato dextrose agar (PDA) (Difco Laboratories). Cultures colonized PDA for 4 to 5 days in the incubator at $23 \pm 2{ }^{\circ} \mathrm{C}$ prior to identification. All isolates 
were maintained in long term storage at room temperature using the following procedure: Three plugs of agar plus mycelium $(4 \mathrm{~mm}$ diameter) from 4- to 5-day-old cultures on PDA were placed in autoclaved screw top glass vials containing $30 \mathrm{ml}$ of sterile water and five autoclaved hemp seeds. After 12 to 14 months in storage, cultures were regrown on PDA or selective medium, evaluated for contamination, and then placed in long term storage again. Cultures for pathogenicity studies were initiated from isolates in long term storage.

Wet mounts of each isolate were made for morphological descriptions. Isolates that did not readily produce sexual structures on PDA were cultured using a grass leaf culture technique that was modified from Abad et al. (1) by Zitnick and Nelson (37). Briefly, tap water was used instead of deionized water to boil a combination of grass clippings (tall fescue, cv. Grande II and Kentucky Bentgrass). The water was allowed to cool, decanted, and saved. Agar plugs with mycelium from 5-day-old cultures were placed in approximately $10 \mathrm{ml}$ of water used to boil the grass clippings in $100 \times 20 \mathrm{~mm}$ petri dishes and incubated at room temperature for 3 to 5 days. Sexual structure production for heterothallic species $(P$. diclinus, $P$. intermedium, $P$. kashmirense, $P$. attrantheridium, $P$. sylvaticum, $P$. heterothallicum, and $P$. inflatum) was accomplished by combining multiple isolates of the same species into one petri dish. All morphological structures for each isolate were examined as described previously. All morphological features were photographed and recorded using an Infinity 2 digital camera and Infinity analysis computer program (Lumenera Corp., Ottawa, Canada).

Morphological features were compared to descriptions of species listed in the identification keys by Plaats-Niterick (28) and Dick (13). These keys do not include a number of newly described species. When an isolate could not be identified using either key, DNA sequence analysis was used as described below to obtain a putative identification. Then, the original publications describing the species were consulted and morphological features of the unknown were compared with those described in the literature.

In addition to morphological features, DNA sequences were also used to identify all isolates to species. The internal transcribed spacer (ITS) sequence is a widely used DNA region that has good resolution and is commonly used by the mycology community for species identification (29). However, because of the large amounts of insertions and deletions in ITS, accurate identification can be hindered (29). In addition, formally described species that are evolutionarily closely related may have similar sequences and lead to erroneous identifications, therefore reinforcing the importance of using both morphology and sequence data to identify unknowns (29). The primers ITS1 (TCCGTAGGTGAACCTGCGG) and ITS4 (TCCTCCGCTTATTGATATGC) were used to amplify a section of the $18 \mathrm{~S}$ region, ITS1, the $5.8 \mathrm{~S}$ region, ITS2, and a section of $28 \mathrm{~S}$ region of ribosomal DNA (7). The DNA extraction and PCR methods are as stated in Broders et al. (7). The DNA extraction and
PCR were performed on all isolates three times to confirm the molecular identification. The DNA sequence data were compared with known sequences that had been deposited in the NCBI nonredundant database to confirm morphological identification or to assist in the identification of isolates where using morphological identification was not attainable. The BLAST parameters for the sequences were sequence lengths, e-values, maximum identity match, and query coverage. The sequence lengths were approximately 800 bp or greater. Identities were selected based on e-values of 0.0 , maximum identity match of $95 \%$ or greater, and a query coverage of $98 \%$ or greater.

Pathogenicity trials. Three isolates of each species, each from a different field, were randomly selected and tested for pathogenicity on soybean. Pathogenicity was defined as a pathogen's ability to cause disease (2). The focus of the pathogenicity trials was to determine pathogenicity of Pythium spp. on soybean and not to compare degree of pathogenicity among species.

Inoculum was prepared using the methods stated in Broders et al. (7) with slight modifications. A soil plus cornmeal substrate was prepared from $237.5 \mathrm{~g}$ of sandy loam soil (La Prairie sandy loam), $12.5 \mathrm{~g}$ of cornmeal, and $80 \mathrm{ml}$ of deionized $\mathrm{H}_{2} \mathrm{O}$ in a $1,000 \mathrm{ml}$ beaker, then autoclaved for $30 \mathrm{~min}$. Subcultures of each isolate on PARP+B medium were plated onto PDA and incubated at $23 \pm 2{ }^{\circ} \mathrm{C}$ for 6 days. A plate containing an isolate was then diced, mixed into the autoclaved soil plus cornmeal substrate, covered with tin foil, and allowed to colonize the substrate for 9 days at room temperature. The substrate was occasionally shaken to enhance inoculum production.

Plastic cups (500 ml; Solo cups, Dart Container Corp., Mason, MI) with drainage holes drilled in the bottom were used to grow plants in the presence of the Pythium species. Approximately $283 \mathrm{~g}$ of autoclaved noninfested La Prairie sandy loam soil was placed into a plastic cup, followed by $83 \mathrm{~g}$ of inoculum, and an additional layer of $114 \mathrm{~g}$ of noninfested autoclaved soil. Ten Barnes soybean seeds were then planted $1.5 \mathrm{~cm}$ deep into each cup with approximately $1.5 \mathrm{~cm}$ between the seed and inoculum. Plants were incubated at $23 \pm 2^{\circ} \mathrm{C}$ in a growth chamber $(19 \mathrm{cu} \mathrm{ft}$; Percival 35LL, Boone, IA) with $12 \mathrm{~h}$ of fluorescent light daily for 14 days. Preliminary experiments at $23^{\circ} \mathrm{C}$ indicated that our positive control, $P$. ultimum, was strongly pathogenic and many of the other species were pathogenic; thus, that temperature was used for all pathogenicity tests. Pathogenicity was assessed using the following criteria: number of emerged seedlings, and number of living seedlings. Results for each species were compared with the positive and the negative controls. The positive control consisted of P. ultimum infested soil. P. ultimum was selected for a positive control because of the extensive documentation citing $P$. ultimum as a highly aggressive pathogen on soybean. The negative control consisted of noninfested soil. Emergence was defined as a plant that broke the soil surface and the cotyledons were visible above the soil surface.

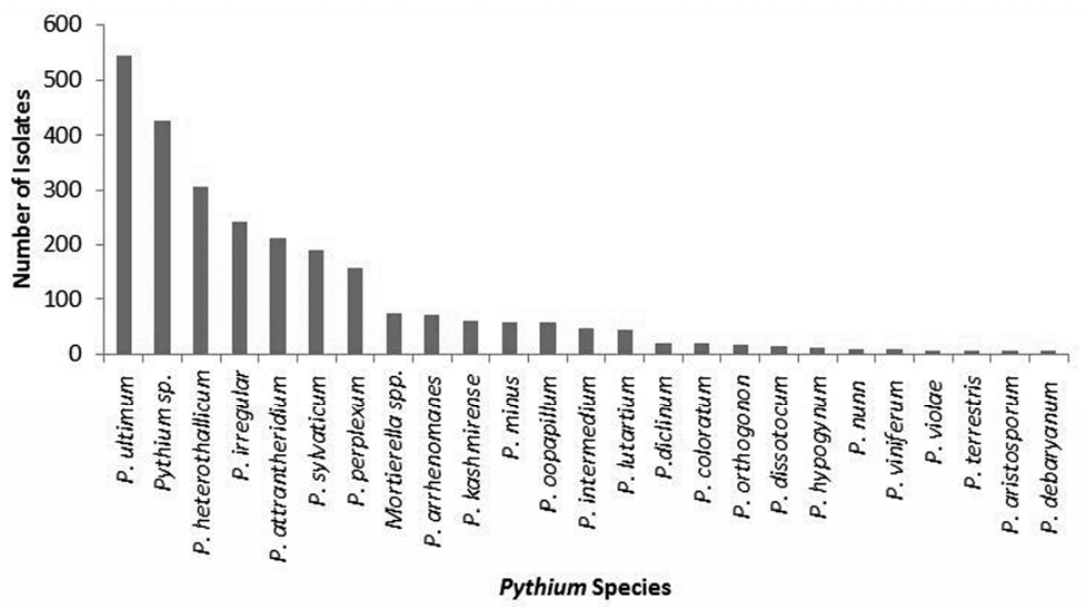

Fig. 1. Frequency distribution of Pythium species for 2,657 isolates recovered from soybean roots collected from 87 fields in North Dakota in 2011. Mortierella is a zygomycete. 
Surviving plants were extracted from the cups and examined for evidence of discoloration, or lesions on the root system or base of the stems. The seeds, roots, and shoots were sampled from plants exhibiting symptoms, and pieces were placed onto PARP+B WA for reisolation and identification of Pythium as previously described.

Isolates from different species were tested in groups of three because of the limited space in the growth chamber. The experimental design was a random design with three replications (each cup as a replicate). Each of the three isolates of a species was tested once at different times; the data from the three isolates of a species were combined to represent the pathogenicity data for that species. Data from the three isolates of a species were combined only if isolates had similar effects on plants. Positive and negative controls were used in all trials. A pathogenicity test was considered

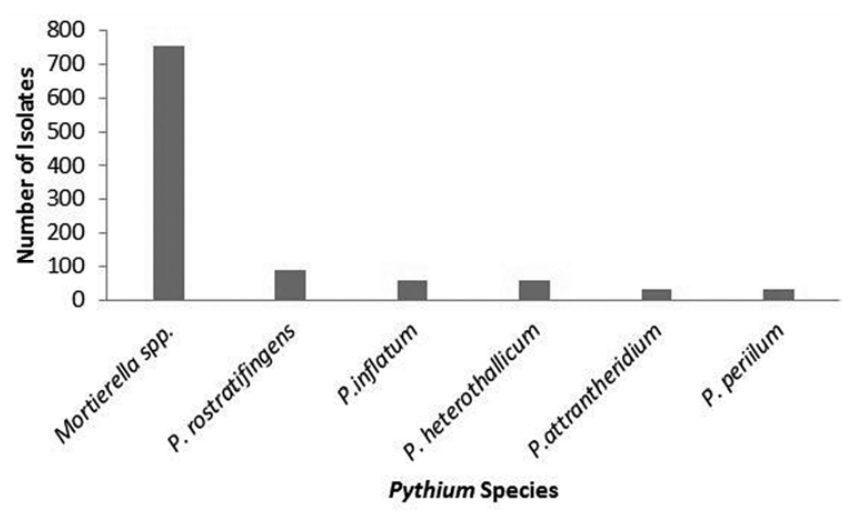

Fig. 2. Frequency distribution of Pythium species and Mortierella out of the 1,024 isolates recovered from soybean roots collected from 38 fields in North Dakota in 2012. Mortierella is a zygomycete. successful only if the results from the positive and negative controls were as expected (the positive control had $<2 \%$ seedling emergence and survival; the negative control had $100 \%$ seedling emergence and survival). Data from all species tested were combined and analyzed using PROC UNIVARIATE in Statistical Analysis System (SAS version 9.1; SAS Institute, Cary, NC). Confidence intervals were obtained for each Pythium species and graphed.

\section{Results}

Isolation and identification. A total of 2,657 isolates of Pythium spp. were recovered from 87 fields in 20 counties during 2011 (Fig. 1; Supplementary table B). Approximately half (43 fields) of the fields sampled in 2011 yielded two or more species. Of the 43 fields, only 25 had plants where multiple species were isolated from a single plant. The 25 fields had approximately four plants per field that yielded more than one Pythium sp. In 2012, only 220 isolates of Pythium spp. were recovered from six fields in three counties, even though 1,024 isolates of Mortierella from 38 fields in 10 counties were initially isolated on the selective medium (Fig. 2). All Pythium spp. isolated in 2012 originated from separate fields. Overall, 26 species (P. attrantheridium, $P$. aristosporum, $P$. arrhenomanes, $P$. coloratum, $P$. debaryanum, $P$. diclinum, $P$. dissoctum, $P$. heterothallicum, $P$. hypogynum, $P$. inflatum, $P$. intermedium, $P$. irregulare, $P$. kashmirense, $P$. lutarium, $P$. minus, $P$. nunn, $P$. oopapillum, $P$. orthogonon, $P$. periilum, $P$. perplexan, $P$. rostratifingens, $P$. sylvaticum, $P$. terrestris, $P$. ultimum, $P$. viniferum, and $P$. viola) of Pythium (Figs. 1 and 2) were identified over the 2 years using both DNA sequence analysis and morphological features. Twenty-four and five species were identified from the 2011 and 2012 root samples, respectively. A substantial portion of the total number of isolates from the 2011 samples was unknown Pythium spp. (Fig. 1). The $16 \%$ that were not able to be identified to species had three accession numbers from the NCBI database. There were 219 isolates that were identified as HQ643829.1 and HQ643823.1,

Table 1. Defining morphological characteristics used to identify six Pythium species not found in the monographs by Plaats-Niterick (1981) and M. W. Dick (1990)

\begin{tabular}{|c|c|c|c|c|c|}
\hline Pythium species & Asexual & Oogonia & Antheridia & Oospore & Growth pattern \\
\hline P. viniferum $^{\mathrm{a}}$ & $\begin{array}{l}\text { Sporangia sickle shaped } \\
\text { appressoria bearing sexual } \\
\text { structure }\end{array}$ & $\begin{array}{l}\text { Intercalary, can be elon- } \\
\text { gated or dumbbell } \\
\text { shaped }\end{array}$ & $\begin{array}{l}\text { Hypogynous, monocli- } \\
\text { nous sessile, or monocli- } \\
\text { nous on short branches }\end{array}$ & $\begin{array}{l}\text { Mainly plerotic, can be } \\
\text { elongated and peanut } \\
\text { shaped }\end{array}$ & $\begin{array}{l}\text { On PDA: colonies are } \\
\text { submerged and } \\
\text { radial/arachnoid } \\
\text { patterned }\end{array}$ \\
\hline P. oopapillum ${ }^{\mathrm{b}}$ & $\begin{array}{l}\text { Sporangia filamentous in- } \\
\text { flated }\end{array}$ & $\begin{array}{l}\text { Mostly intercalary, } \\
\text { smooth, globose }\end{array}$ & $\begin{array}{l}1 \text { to } 2 \text { per oogonium, } \\
\text { monoclinous, diclinous } \\
\text { on branched stalks club- } \\
\text { shaped, making apical or } \\
\text { lateral contact }\end{array}$ & $\begin{array}{l}\text { Thick-walled and with a } \\
\text { papilla }\end{array}$ & $\begin{array}{l}\text { On PDA: chrysanthe- } \\
\text { mum patterned }\end{array}$ \\
\hline P. rostratifingens ${ }^{\mathrm{c}}$ & $\begin{array}{l}\text { Sporangia intercalary, occa- } \\
\text { sionally terminal/oval, dis- } \\
\text { charge tubes up to } 30 \mu \mathrm{m} \\
\text { long, many sporangia do } \\
\text { not develop zoospores }\end{array}$ & $\begin{array}{l}\text { Intercalary, globose, and } \\
\text { smooth }\end{array}$ & $\begin{array}{l}1 \text { to } 4 \text {, mainly } 2 \text { per oogo- } \\
\text { nium, monoclinous, oc- } \\
\text { casionally diclinous, on } \\
\text { short stalk or hypogy- } \\
\text { nous }\end{array}$ & $\begin{array}{l}\text { Wall thickness up to } 1.5 \\
\mu \mathrm{m}\end{array}$ & $\begin{array}{l}\text { On PDA: colonies are } \\
\text { submerged and chry- } \\
\text { santhemum patterned }\end{array}$ \\
\hline P. terrestris ${ }^{\mathrm{d}}$ & $\begin{array}{l}\text { Sporangia globose and can } \\
\text { be elongated, mainly inter- } \\
\text { calary, has short discharge } \\
\text { tubes }\end{array}$ & $\begin{array}{l}\text { Smooth walled, interca- } \\
\text { lary, and densely filled } \\
\text { with protoplasm }\end{array}$ & $\begin{array}{l}\text { Hypogynous or monocli- } \\
\text { nous which can coil } \\
\text { around oogonial stalk } \\
\text { and form a knot }\end{array}$ & $\begin{array}{l}\text { Aplerotic, wall thickness } \\
\text { between } 2 \text { and } 4 \mu \mathrm{m}\end{array}$ & $\begin{array}{l}\text { On PDA: colonies are } \\
\text { submerged narrow } \\
\text { chrysanthemum } \\
\text { patterned }\end{array}$ \\
\hline$P$. attrantheridium ${ }^{\mathrm{e}}$ & $\begin{array}{l}\text { Sporangia only produced by } \\
+ \text { mating type, terminal/ } \\
\text { intercalary, globose, dis- } \\
\text { charge tube } 27 \mu \mathrm{m} \text { in } \\
\text { length }\end{array}$ & $\begin{array}{l}\text { Terminal, } 0.5 \mu \mathrm{m} \text { wall } \\
\text { thickness }\end{array}$ & $\begin{array}{l}\text { Diclinous, vanishes after } \\
\text { fertilization, inflated and } \\
\text { broad apical attachment }\end{array}$ & $\begin{array}{l}\text { Plerotic or aplerotic, } 1.5 \\
\mu \mathrm{m} \text { wall thickness }\end{array}$ & $\begin{array}{l}\text { On PDA: + mating } \\
\text { type vague radiate } \\
\text { patterned, - mating } \\
\text { type chrysanthemum } \\
\text { patterned }\end{array}$ \\
\hline P. kashmirense $\mathrm{k}^{\mathrm{f}}$ & $\begin{array}{l}\text { Numerous, filamentous, } \\
\text { inflated, contiguous }\end{array}$ & $\begin{array}{l}\text { Mainly intercalary, } \\
\text { chain-like formation, } \\
\text { densely filled with } \\
\text { granular protoplasm }\end{array}$ & $\begin{array}{l}\text { Diclinous, tight/loose coil- } \\
\text { ing around oogonial } \\
\text { stalk, } 1 \text { to } 6 \text { antheridia } \\
\text { attached to the oogonia }\end{array}$ & $\begin{array}{l}\text { Both aplerotic/plerotic, } \\
\text { only one ooplast per } \\
\text { oogonium, spherical, } \\
\text { very thin wall } 0.75 \text { to } \\
2 \mu \mathrm{m} \text { wide }\end{array}$ & $\begin{array}{l}\text { On PDA: colonies } \\
\text { submerged, broad } \\
\text { chrysanthemum } \\
\text { patterned }\end{array}$ \\
\hline
\end{tabular}

\footnotetext{
a Paul et al. 2008.

b Bala et al. 2010 .

c de Cock and Levesque, 2004.

d Paul 2002.

e Allain-Boulé et al 2004.

f Paul and Bala 2008.
} 
but based on the BLASTn parameters, the isolates could not be differentiated between the two GenBank accession numbers. There were 252 isolates that were identified as HQ643777.1, the most frequently occurring of the three unknown Pythium spp.

The results of the Pythium spp. identification using DNA sequence analysis, on occasion, yielded multiple identities of a single isolate according to the NCBI database. Therefore, species identification in these cases was based primarily on morphological features and comparing those of the unknowns to the various species identified by sequence analysis. However, the most recent Pythium identification key (13) did not include six species identified by sequence analysis ( $P$. attrantheridium, $P$. kashmirense, $P$. oopapillum, $P$. rostratifingens, $P$. terrestris, and $P$. viniferum). Original publications $(3,4,12,25-27)$ first describing those six species were used to match the morphological features (Table 1) with the unknowns to confirm the identification by sequence analysis. Examples of the unique features used for identification of the six species include structure and ornamentation of the sporangia and oogonia, and number/placement of antheridia on oogonia (Fig. 3). Isolates with accession numbers HQ643829.1, HQ643823.1, and

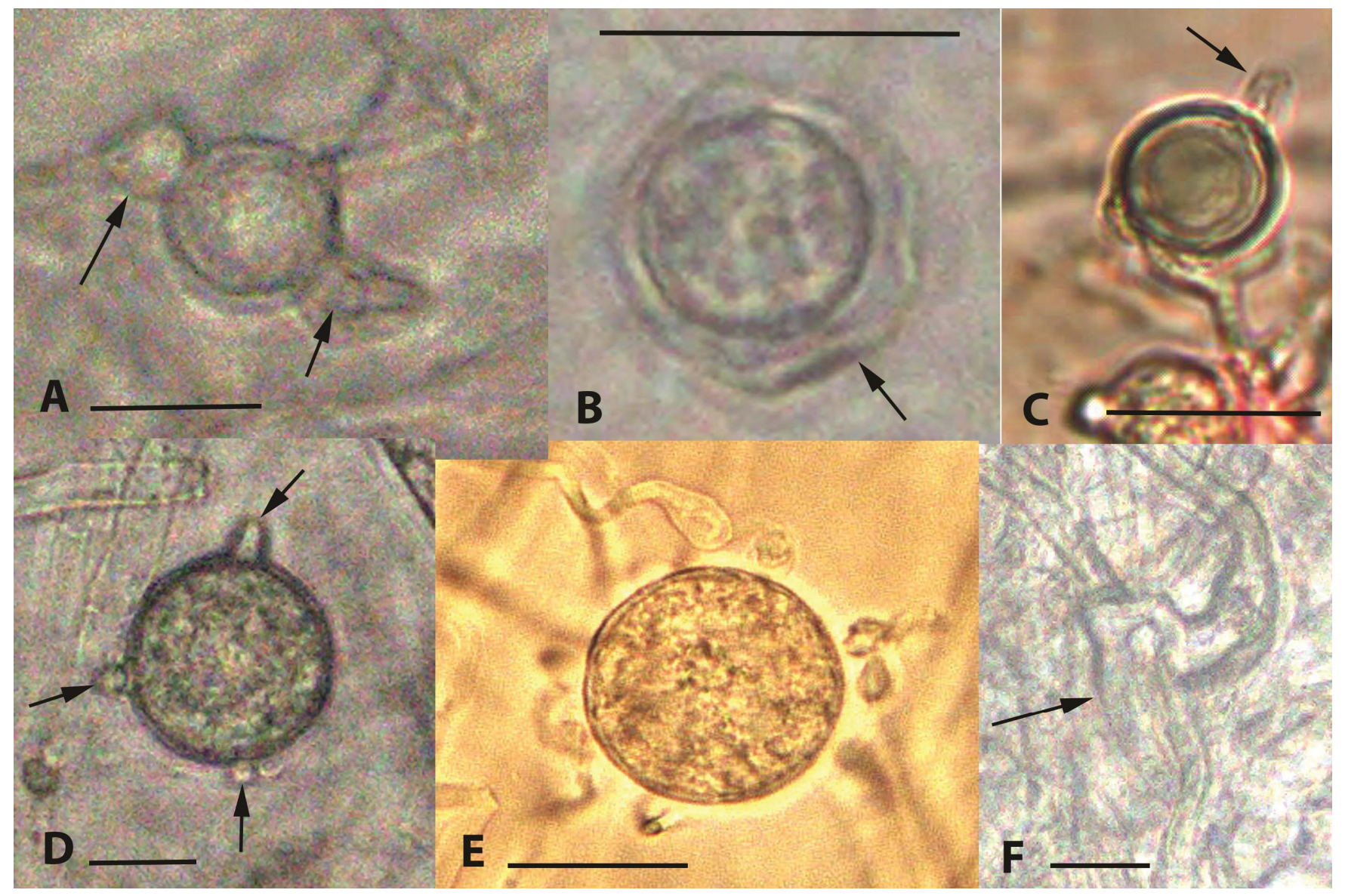

Fig. 3. Examples of unique features of six Pythium species: $\mathbf{A}$, an intercalary oogonium with hypogynous antheridia (arrows) of $P$. rostratifingens; $\mathbf{B}$, wavy exterior oospore wall (arrow), P. attrantheridium; C, thick walled oospore with papillae (arrow), P. oopapillum; D, papillated sporangia (arrows) P. terrestris; E, oogonium with multiple antheridia, $P$. kashmirense; $\mathbf{F}$, sickle shaped sporangia bearing elongated oogonium (arrow), P. viniferum.

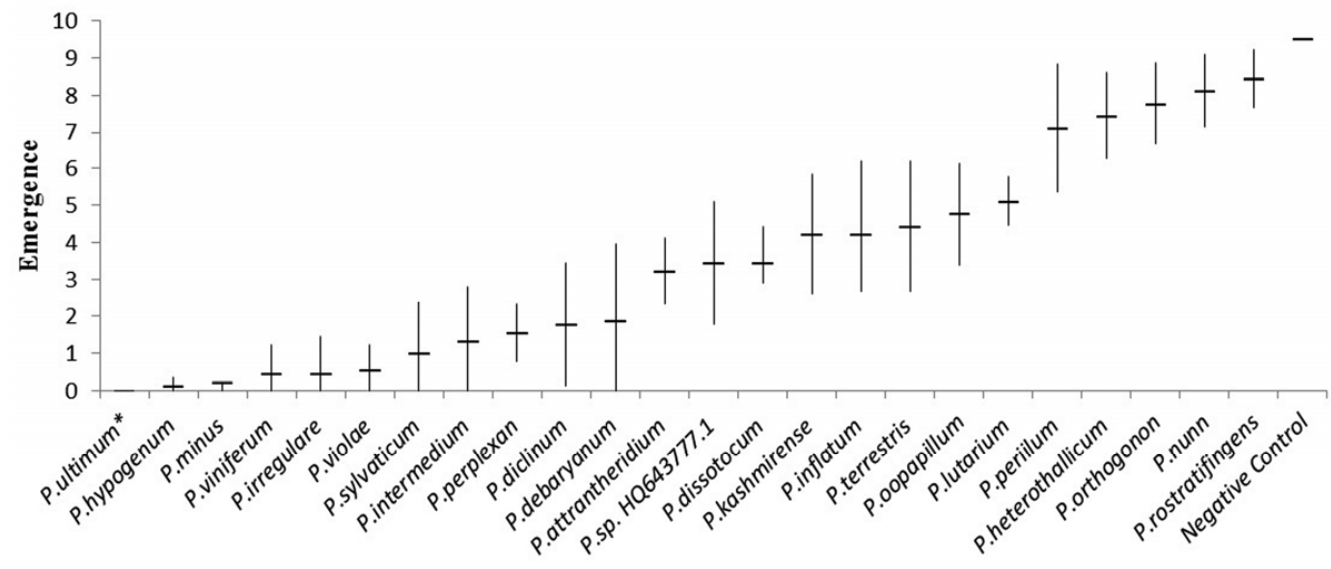

Pythium Species

Fig. 4. Confidence intervals (95\%) for emergence of soybean plants in the presence of Pythium sp. Data are the average number of plants per replicate combined over three experiments. Plants were grown for two weeks in cups containing autoclaved soil artificially infested with Pythium species. The asterisk indicates the positive control with $P$. ultimum. The negative control had non-infested soil. Emergence was defined as any seedling that broke the soil surface. 
HQ643777.1 have yet to be described as a species. A number of single isolates had sequences that were a $100 \%$ identity match to both accession numbers HQ643829.1 and HQ643823.1. Therefore, the identity for many isolates based on sequence analysis was deemed inconclusive. All isolates identified to species by sequence analysis had e-values of 0.0 , maximum identity match of $95 \%$ or greater (only two were less than $99 \%$ ), and query coverages of $96 \%$ or greater to reference (only five were less than $100 \%$ ) GenBank accessions.

In 2011, the three most abundant species isolated were $P$. ultimum, Pythium sp. (unknown; GenBank HQ643777.1), and P. heterothallicum, representing 21,16 , and $12 \%$ of the total isolates, respectively (Fig. 1). Four species, $P$. irregular, $P$. attrantheridium, $P$. sylvaticum, and $P$. perplexum represented $9,8,7$, and $6 \%$ of the isolates, and the remaining 20 species and Mortierella each represented $3 \%$ or fewer of the isolates. The three most abundant species isolated during 2012 were $P$. rostratifingens, $P$. inflatum, and $P$. heterothallicum, representing 9,6 , and $6 \%$ of the total isolates, respectively (Fig. 2). In addition to Pythium spp., the zygomycete Mortierella was isolated on the selective medium, identified morphologically and molecularly, and was the most prevalent organism isolated in 2012.
Pathogenicity trials. Confidence intervals, generated at the $95 \%$ confidence level, indicated that there were no differences in preemergence damping-off and survival of plants among 20 of the Pythium species (Figs. 4 and 5). The majority of Pythium spp. (P. attrantheridium, $P$. debaryanum, $P$. diclinum, $P$. dissotocum, $P$. heterothallicum, $P$. hypogynum, $P$. inflatum, $P$. intermedium, $P$. irregulare, $P$. kashmirense, $P$. lutarium, $P$. minus, $P$. oopapillum, $P$. perplexum, $P$. terrestris, $P$. viniferum, $P$. violae, and Pythium $\mathrm{sp}$ (unknown; GenBank HQ643777.1)) caused pre-emergence damping-off on soybean with less than $50 \%$ seedling emergence compared with the negative control, which had $100 \%$ seedling emergence, and the positive control, which had $<2 \%$ seedling emergence (Fig. 4). P. orthogonon, P. nunn, and P. rostratifingens were different from the other Pythium spp. in their effect on survival.

Two Pythium spp., P. periilum and P. heterothallicum, had approximately 70 to $75 \%$ emergence but less than $20 \%$ of the plants survived 2 weeks after planting (Figs. 4 and 5). In contrast, $P$. orthogonon, P. nunn, and P. rostratifingens had approximately $80 \%$ or greater seedling emergence (Fig. 4) and at the end of the 2 week period all seedlings appeared healthy based on above ground appearance (Fig. 5). The other Pythium spp. had zero to $45 \%$ seedling

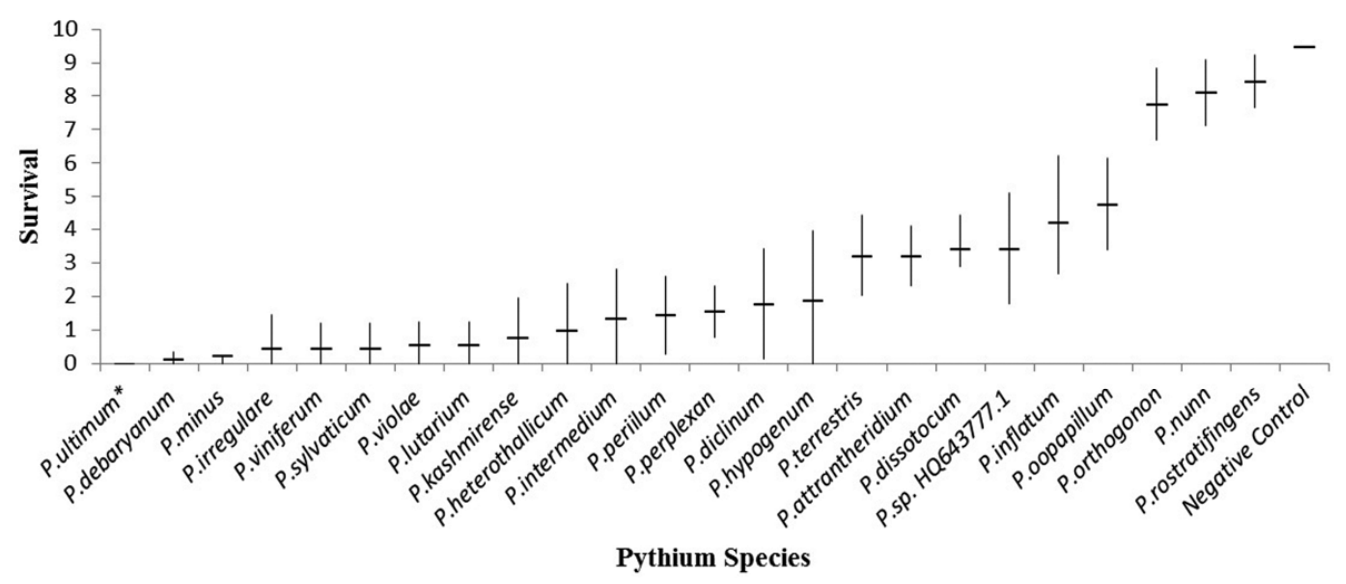

Fig. 5. Confidence intervals (95\%) for survival of soybean plants in the presence of Pythium sp. Data are the average number of plants per replicate combined over three experiments. Plants were grown for 2 weeks in cups containing autoclaved soil artificially infested with Pythium species. The asterisk indicates the positive control with $P$. ultimum. The negative control had non-infested soil. Survival was defined as any plant that did not damp-off or die.

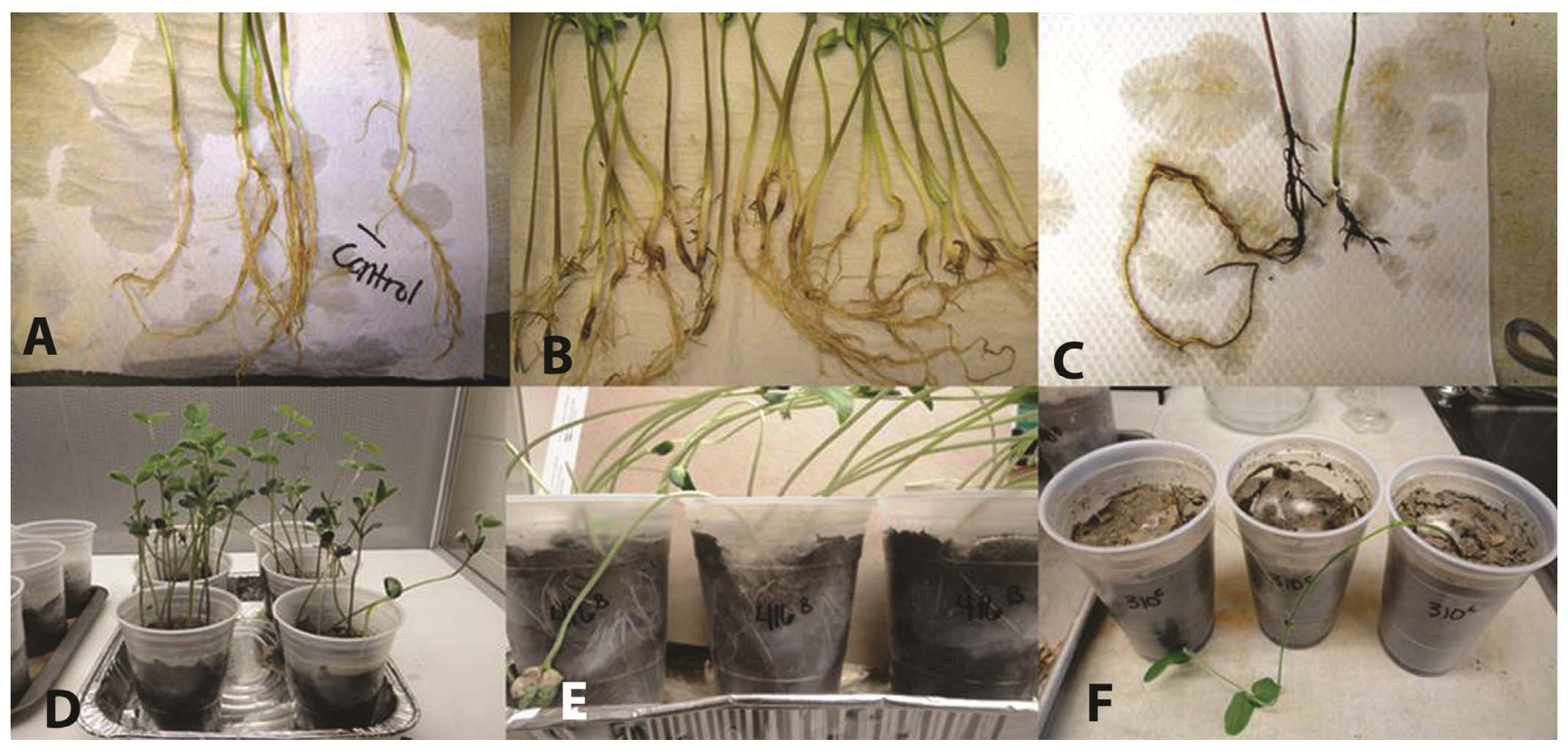

Fig. 6. Pathogenicity of Pythium rostratifingens on soybean cultivar Barnes. The positive (+) control was $P$. ultimum and the negative (-) control was non-infested soil. A, (-) control; B, P. rostratifingens; C, (+) control; D, (-) control, middle row; E, P. rostratifingens; F, (+) control. 
survival after the 2 weeks (Fig. 5). However, most surviving plants in all species except $P$. orthogonon, $P$. nunn, and $P$. rostratifingens were stunted, discolored, and had numerous lesions on the roots/shoots similar to those shown in Figures 6 and 7. Although the surviving plants of $P$. orthogonon, $P$. nunn, and $P$. rostratifingens appeared healthy, the roots of those plants had small $(4 \mathrm{~cm}$ long), brown lesions (Fig. 6). P. coloratum, P. aristosporum, and $P$. arrhenomanes were not included in the pathogenicity trials, because they could not be recovered from long term storage after 12 to 14 months. Also, the two unknown Pythium spp. with multiple identifications by sequencing were not tested for pathogenicity; their identity and pathogenicity will be addressed in a separate study. Mortierella spp. were not the focus of the study and therefore were not tested for pathogenicity. All Pythium spp. tested were reisolated from lesions on infected plants and reidentified using the methods previously described.

\section{Discussion}

Knowledge of Pythium spp. diversity on soybean in the northern Great Plains, specifically in North Dakota, is limited. Only recently have a number of studies in the northern Great Plains begun to describe the species associated with soybean and/or characterize their pathogenicity $(10,17,24,30)$. Probably the earliest study on Pythium spp. associated with soybean in the region was by Brown and Kennedy in 1965 (9) who reported P. ultimum and P. debaryanum as the two species found in roots in Minnesota. This current study indicates that there is a highly diverse community of pathogenic Pythium spp. associated with soybean roots in the northern soybean production area.

The problems and concerns researchers can have when only using sequence based identification of oomycetes, have been addressed in several recent publications $(18,29,32)$. The reader is referred to the excellent review by Schroeder et al. (32) on taxonomy and current and future methods of identification of Pythium spp. An example of how problematic using only sequence data can be for identification was when select isolates from 2011 were morphologically identified as $P$. coloratum but, according to the NCBI database, the isolate had a $100 \%$ sequence match to $P$. dissotocum, $P$. diclinum, and $P$. coloratum. Through the process of elimination, $P$. coloratum was determined to be the identity based on the fact that the isolate had branched antheridia, eliminating $P$. dissotocum, and the presence of both mono- and diclinous antheridia, eliminat- ing $P$. diclinum. This research demonstrates the benefit of using both morphological and DNA sequence based identification when identifying species of Pythium. In addition to clarifying conflicting results, employing both techniques can also help confirm unusual results such as the identification of $P$. kashmirense, $P$. viniferum, and $P$. terrestris from soybean roots in 2011. These three Pythium species were reported to occur in India, Turkey, and France, respectively, but not in the United States.

A Pythium species complex on individual soybean plants was not observed as frequently as previous research indicated $(8,34)$. In contrast to a complex, the results from the 2011 survey indicated that only one species was isolated from the majority of the plants sampled even though over half of the fields sampled in 2011 had more than one Pythium species present. A possibility as to why it was more common to isolate one species from one plant could be interspecific competition between Pythium species, changes within the soil environment, or the type of soybean cultivar grown in an area.

In 2011, 24 Pythium spp. were isolated from soybean roots, while in 2012 there were only five species isolated. In addition, there were approximately eight times the number of Pythium spp. isolates obtained from soybean roots in 2011 compared with 2012. Pythium spp. were obtained from 87 fields in 2011 and only six fields in 2012. This large difference in species diversity and number of Pythium isolates between the 2 years was probably caused by differences in soil moisture and temperature. Oomycetes are generally more active in a cool/wet climate (23) and there was a difference in climate between the two years with 2012 a far drier year than 2011. Soybeans are typically planted in May in North Dakota and the root samples in this study were obtained in June of each year. A comparison of the average soil temperatures at 10.2 $\mathrm{cm}$ depth from 10 weather stations in the eastern half of North Dakota revealed that the average soil temperature for the combined months of May and June was $15.2^{\circ} \mathrm{C}$ in 2011 and $18.1^{\circ} \mathrm{C}$ in 2012 (all data from the North Dakota Agricultural Weather Network, http://ndawn.ndsu.nodak.edu/). The average air temperature for May and June was $14.6^{\circ} \mathrm{C}$ in 2011 and $16.6^{\circ} \mathrm{C}$ in 2012 . The rainfall during April to June at those same 10 weather stations was approximately $25 \mathrm{~cm}$ in 2011 compared with $16.0 \mathrm{~cm}$ in 2012 . Thus, soil and air temperatures were cooler, and soil moisture was likely greater for soybean during the seedling stage in 2011 compared with 2012. The reduction in moisture and warmer temperatures during the seedling stage in 2012 possibly reduced or inhibited the

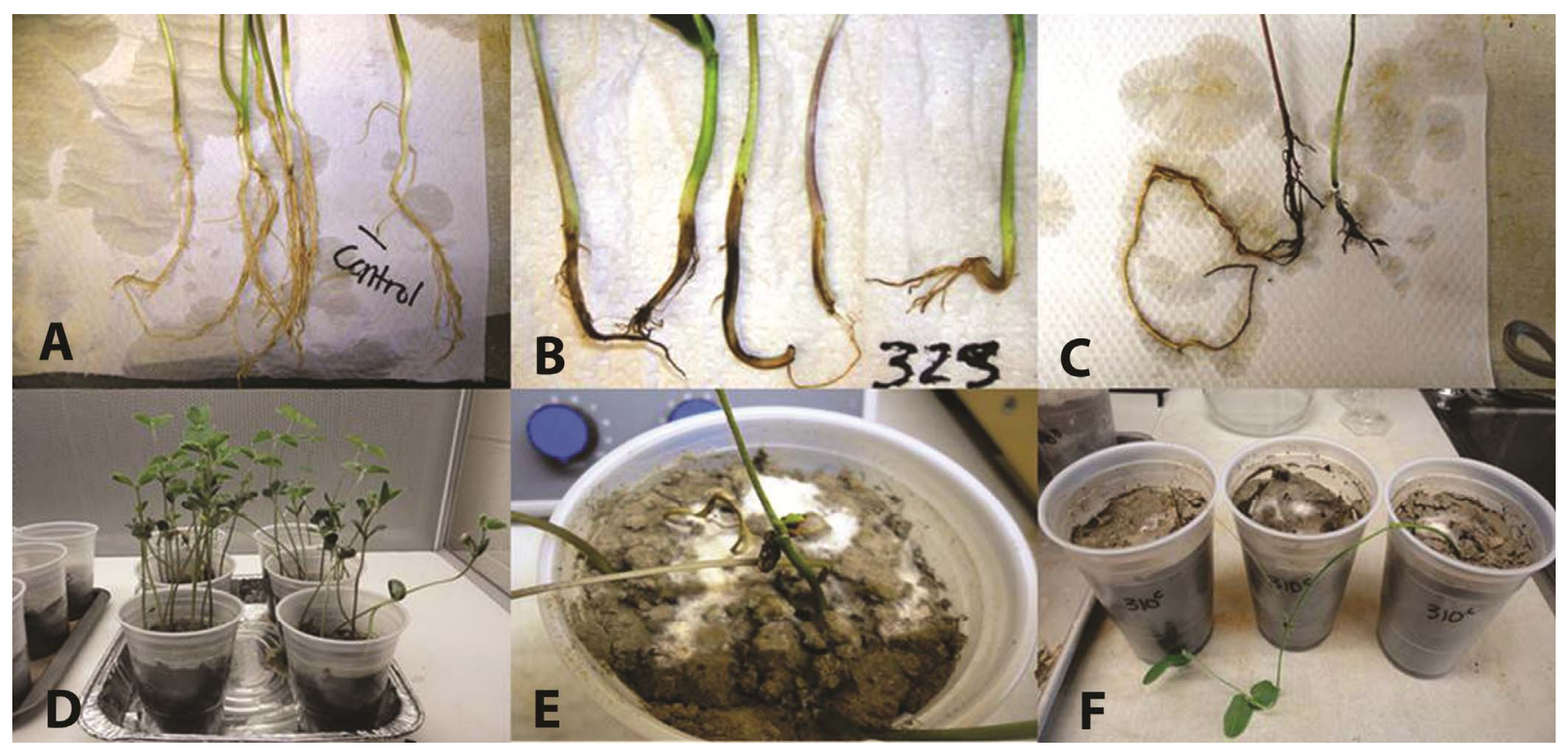

Fig. 7. Pathogenicity of $P$. oopapillum on soybean cultivar Barnes. The positive $(+)$ control was $P$. ultimum and the negative (-) control was non-infested soil. A, $(-)$ control; B, P. oopapillum; C, (+) control; D, (-) control, middle row; E, P. oopapillum; F, (+) control. 
germination/growth of many Pythium spp., thus reducing colonization of soybean roots and isolation of Pythium species. Pythium spp. pathogenic on soybean are reported to have different temperature requirements for infection (24).

The zygomycete Mortierella was included in the data on the Pythium spp. since Mortierella was isolated along with the Pythium spp. on the selective medium and was the dominant organism isolated from soybean roots in 2012. Although there are many different fungal and fungal-like organisms in soybean roots (19), this high frequency of recovery of Mortierella we considered unusual and thus is reported here. A similar report of such high frequency of Mortierella isolated from soybean roots has not been found. Furthermore, this high frequency of Mortierella also points out the stark difference in isolation of Pythium spp. from soybean roots in a wetter versus a drier period during the early part of the growing season. The morphology of Mortierella on the selective medium in the first 2 to 5 days following isolation is similar to the Pythium spp. The hyphae are coenocytic and the growth patterns are similar to Pythium spp., i.e., chrysanthemum, pulvinate, etc. Mortierella is a soil fungus that is known as an early colonizer of roots and is reported to be associated with soybean roots $(6,15)$, but is usually nonpathogenic on plants and animals with the exception of $M$. wolfii, which is an animal pathogen (11). Recent research found a Mortierella sp. in conjunction with arbuscular mycorrhizal fungi, which was shown to significantly increase shoot/root dry weight of the herbaceous halophyte Kostelelzkya virginica when grown under saline conditions (35). This fast growing genus thrives best in drier soil conditions, which would explain why it was commonly isolated from roots in 2012 but not in 2011. The role that Mortierella plays in the microbial colonization of soybean roots should be investigated.

The three species that were not evaluated for pathogenicity, $P$. coloratum, $P$. aristosporum, and $P$. arrhenomanes, had been in storage for 12 to 14 months, and all attempts to revive the cultures were unsuccessful. A number of Pythium spp., such as $P$. oopapillum, have been reported to be difficult to maintain in storage (4). It is critical to avoid bacterial contamination of the storage medium, as many isolates were difficult to recover if contamination occurred. Fortunately, 95\% of isolates obtained in this study were successfully stored for 12 to 14 months, regrown on PDA, and stored again for another 12 to 14 months.

Although pathogenicity has been previously recorded for certain Pythium species on soybean, this study yielded species for which pathogenicity on soybean was unknown. All Pythium spp. identified, with the exception of $P$. orthogonon and $P$. nunn, have been documented pathogens on a wide host range (Citrus, Pinus, turfgrass, etc.). P. attrantheridium, $P$. debaryanum, $P$. diclinum, $P$. dissotocum, $P$. heterothallicum, $P$. hypogynum, $P$. inflatum, $P$. intermedium, $P$. irregular, $P$. lutarium, $P$. oopapillum, $P$. orthogonon, $P$. perplexum, $P$. sylvaticum, and $P$. ultimum have previously been documented as pathogens on soybeans $(7,17,24,28)$. This is the first report of $P$. kashmirense, $P$. minus, $P$. periilum, $P$. perplexum, $P$. rostratifingens, $P$. terrestris, $P$. viniferum, and $P$. violae as pathogens of soybean seedlings in the United States. The pathogenicity trials corroborate previously recorded results and indicate that the majority of the species collected were pathogenic on soybean $(7,17)$. The results also indicate that all but three Pythium spp. ( $P$. orthogonon, $P$. nunn, and $P$. rostratifingens) cause pre-emergence damping-off. All Pythium spp. were able to cause lesions on the roots of soybean seedlings, suggesting that all species including previously recorded beneficial species were capable of causing infection on soybean. All but three species (P. orthogonon, P. nunn, and $P$. rostratifingens) resulted in fewer than $50 \%$ of the seedlings surviving after a 2 week period. However, if the pathogenicity study had continued over a longer period, post-emergence damping-off may have occurred with the surviving plants because of the presence of numerous black/brown necrotic lesions on the roots. Although pathogenicity tests with $P$. orthogonon, $P$. nunn, and $P$. rostratifingens resulted in approximately $80 \%$ of the seedlings surviving for 2 weeks and remaining visibly healthy, small $(4 \mathrm{~cm}$ long) brown lesions were present on the tap roots. $P$. nunn has been documented as antagonistic to P. ultimum and suggested for use as a biocontrol agent (20). Contrary to previous studies, the presence of lesions on the roots indicates that $P$. nunn is capable of causing some disease on soybean (20-22). There is evidence that species may differ in pathogenicity at different temperatures $(24,34)$. Only one temperature was used in this study; thus, the results may be different at other temperatures. Future studies on which species are pathogenic at certain temperatures more commonly found during planting may provide useful data toward understanding the importance of individual species. In addition, the host range of many of these Pythium species is unknown and merits investigation. Cropping patterns may be a factor in the presence and abundance of species.

In conclusion, there is a diverse population of Pythium spp. associated with soybean roots in the northern soybean growing area of the Great Plains of the United States. Twenty-six known species and three unknown species were associated with soybean roots in this study. One of the most prevalent species isolated was a pathogenic unknown, emphasizing the importance of further research on the isolate for proper identification. Many of these species are pathogenic on soybean seedlings and may play a role in seed rot and damping-off of soybeans in commercial soybean planting. Understanding the biology of these various species will be important for developing strategies for control of seedling disease caused by Pythium species. This is the first report of $P$. kashmirense, $P$. minus, $P$. periilum, $P$. rostratifingens, $P$. terrestris, $P$. viniferum, and $P$. violae as pathogens of soybean seedlings. In addition, this is the first report of P. kashmirense, $P$. viniferum, and $P$. terrestris in the United States.

\section{Acknowledgments}

We thank the North Dakota Soybean Council for funding this research and Tracy Christianson and Susilo Poromarto for help in collecting samples. We are grateful for advice from G. W. Moorman on working with Pythium.

\section{Literature Cited}

1. Abad, Z. G., Shaw H. D., and Lucas, L. T. 1994. Characterization and pathogenicity of Pythium species isolated from turfgrass with symptoms of root and crown rot in North Carolina. Phytopathology 84:913-921.

2. Agrios, G. N. 2005. Plant Pathology. Elsevier Academic Press, New York.

3. Allain-Boulé, N., Tweddell, R., Mazzola, M., Bélanger, R., and Lévesque, C. A. 2004. Pythium attrantheridium sp. nov.: taxonomy and comparison with related species. Mycol. Res. 108:795-805.

4. Bala, K., Robideau, G. P., Desauliners, N., de Cock, A. W. A. M., and Levesque, C. A. 2010. Taxonomy, DNA barcoding and phylogeny of three new species of Pythium from Canada. Persoonia 25:22-31.

5. Beakes, G. W., Glocking, S. L., and Sekinoto, S. 2012. The evolutionary phylogeny of the oomycete fungi. Protoplama 249:3-19.

6. Bienapfl, J. C., Malvick, D. K., and Percich, J. A. 2010. Identification and characterization of fungal communities associated with soybean roots in Minnesota. Phytopathology 100:S14.

7. Broders, K. D., Lipps, P. E., Paul, P. A., and Dorrance, A. E. 2007. Characterization of Pythium spp. associated with corn and soybean seed and seedling disease in Ohio. Plant Dis. 91:727-735.

8. Broders, K. D., Wallhead, M. W., Austin, G. D., Lipps, P. E., Paul, P. A., Mullen, R. W., and Dorrance, A. E. 2009. Association of soil chemical and physical properties with Pythium species diversity, community composition, and disease incidence. Phytopathology 99:957-967.

9. Brown, G. E., and Kennedy, B. W. 1965. Pythium pre-emergence dampingoff of soybeans in Minnesota. Plant Dis. Reptr. 49:646-647.

10. Chase, T. E., and Bartlett, P. B. 2013. Oomycetes isolated from soybeans with damping-off in South Dakota. Phytopathology. 103:S2.25

11. Davies, J. L., and Wobeser, G. A. 2010. Systemic infection with Mortierella wolfii following abortion in a cow. Can. Vet. J. 51:1391-1393.

12. de Cock, A. W. A. M., and Lévesque, C. A. 2004. New species of Pythium and Phytophthora. Stud. Mycol. 50:481-487.

13. Dick, M. W. 1990. Key to Pythium. University of Reading Press, Reading, UK.

14. Hartman, G. L., Sinclair, J. B., and Rupe, J. C., eds. 1999. Compendium of Soybean Diseases. American Phytopathological Society, St. Paul, MN.

15. Ivarson, K. C., and Mack, A. R. 1972. Root surface mycoflora of soybean in relation to soil temperature and moisture in a field environment. Can. J. Soil Sci. 52:199-208.

16. Jeffers, S. N., and Martin, S. B. 1986. Comparison of two media selective for Phytophthora and Pythium species. Plant Dis. 70:1038-1043.

17. Jiang, Y. N., Haudenshield, J. S., and Hartman, G. L. 2012. Characterization 
of Pythium spp. from soil samples in Illinois. Can. J. Plant Pathol. 34:448454.

18. Kang, S., Mansfield, M. A., Park, B., Geiser, D. M., Ivors, K. L., Coffey, M. D., Grünwald, N. J., Martin, F. N., Lévesque, C. A., and Blair, J. E. 2010. The promise and pitfalls of sequence-based identification of plant pathogenic fungi and oomycetes. Phytopathology 100:732-737.

19. Killebrew, J. F., Roy, K. W., and Abney, T. S. 1993. Fusaria and other fungi on soybean seedlings and roots of older plants and interrelationships among fungi, symptoms, and soil characteristics. Can. J. Plant Pathol. 15:139-146.

20. Kobayashi, S., Uzuhashi, S., Tojo, M., and Kakishima, M. 2010. Characterization of Pythium nunn newly recorded in Japan and its antagonistic activity against $P$. ultimum var. ultimum. J. Gen. Plant Pathol. 76:278-283.

21. Lifshitz, R., Dupler, M., Elad, Y., and Baker, R. 1984. Hyphal interactions between a mycoparasite, Pythium nunn and several soil fungi. Can. J. Microbiol. 30:1482-1487.

22. Lifshitz, R., Sneh, B., and Baker, R. 1984. Soil suppressiveness to plant pathogenic Pythium species. Phytopathology 74:1054-1061.

23. Martin, F. N., and Loper, L. E. 1999. Soilborne plant diseases caused by Pythium spp.: Ecology, epidemiology, and prospects for biological control. Crit. Rev. Plant Sci. 18:111-181.

24. Matthiesen, R. L., and Robertson, A. E. 2013. Pathogenicity of Pythium species affecting corn and soybean in Iowa at three temperatures using two assay methods. Phytopathology 103:S2.92.

25. Paul, B. 2002. Pythium terrestris, a new species isolated from France, its ITS region, taxonomy and its comparison with related species. FEMS Microbiol. Lett. 212:255-260.

26. Paul, B., and Bala, K. 2008. A new species of Pythium with inflated sporangia and coiled antheridia, isolated from India. FEMS Microbiol. Lett. 282:251-257.

27. Paul, B., Mathew, R., Kanak, B., Paul, A., Henry, M., Lefort, F., and Belbahri, L. 2008. Morphology, taxonomy, and phylogenetic analysis of a new species of Pythium isolated from France. Fungal Divers. 28:55-63.

28. Plaats-Niterick, A. J. van der. 1981. Monograph of the genus Pythium. Stud. Mycol. 21:1-242.
29. Robideau, G. P., de Cock, A. W. A. M., Coffey, M. D., Voglmayr, H Brouwer, H., Bala, K., Chitty, D. W., Désaulniers, N., Eggertson, Q. A. Gachon, C. M. M., Hu, C., Küpper, F. C., Rintoul, T. L., Sarhan, E., Verstappen, E. C. O., Zhang, Y., Bonants, P. J. M., Ristaino, J. B., and Lévesque, C. A 2011. DNA barcoding of oomycetes with cytochrome c oxidase subunit I and internal transcribed spacer. Mol. Ecol. Res. 11:1002-1011.

30. Rojas, A., Jacobs, J. L., Napieralski, S., Bradley, C. A., Chase, T., Esker, P. D., Giesler, L., Jardine, D., Nelson, B. D., Malvick, D., Markell, S., Robertson, A. E., Rupe, J. C., Sweets, L., Wise, K., and Chilvers, M. I. 2013. Diversity of oomycetes associated with soybean seedling diseases in the U.S. Phytopathology 103:S2.123.

31. Schmitthenner, A. F., and Bhat, R. G. 1994. Useful methods for studying Phytophthora in the laboratory. Ohio Agricultural Research and Development Center, Special Circular 143.

32. Schroeder, K. L., Martin, F. N., de Cock, W. A. M., Lévesque, C. A., Spies, C. F. J., Okubara, P. A., and Paulitz, T. C. 2013. Molecular detection and quantification of Pythium species: Evolving taxonomy, new tools, and challenges. Plant Dis. 97:4-20.

33. Tsao, P. H., and Ocana, G. 1969. Selective isolation of species of Phytophthora from natural soils on an improved antibiotic medium. Nature. 223:636-638.

34. Wei, L., Xue, A. G., Cober, E. R., Babock, C., Zhang, J., Zhang, S., Li, W., Wu, J., and Liu, L. 2011. Pathogenicity of Pythium species causing seed rot and damping-off in soybean under controlled conditions. Phytoprotection 91:3-10.

35. Zhang, H., Wu, X., Li., G., and Qin, P. 2011. Interactions between arbuscular mycorrhizal fungi and phosphate-solubilizing fungus (Mortierella sp.) and their effects on Kostelelzkya virginica growth and enzyme activities of rhizosphere and bulk soils at different salinities. Biol. Fertil. Soils 47:543-554.

36. Zitnick-Anderson, K., and Nelson, B. 2012a. Characterization and identification of Pythium from soybean roots in North Dakota. Phytopathology 102:S4.145

37. Zitnick-Anderson, K., and Nelson, B. 2012b. Stimulation of sexual structure production by Pythium. Phytopathology. 102:S4.145. 